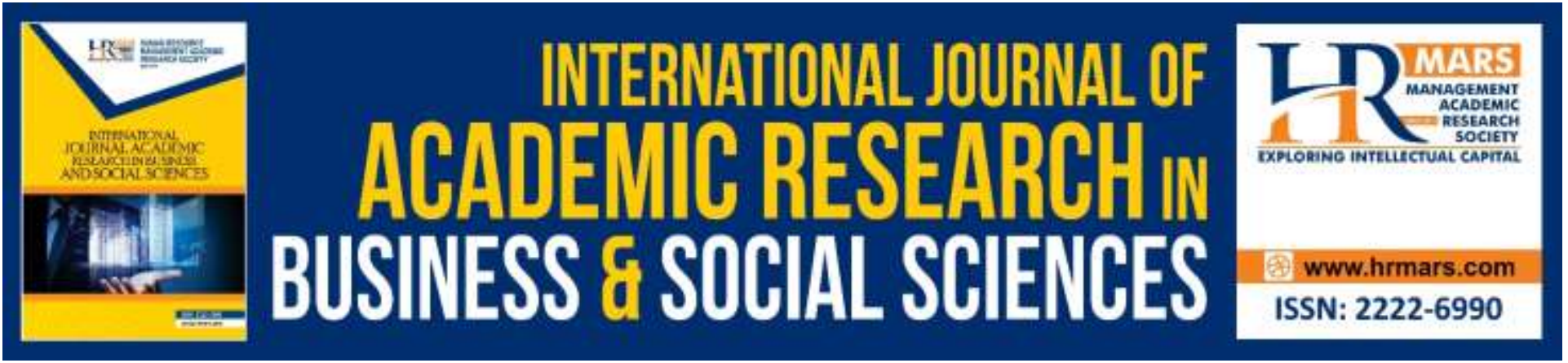

\title{
Evaluation of the Economic Theme in Historical Curriculum in Middle School in Providing Entrepreneurial Spirit Generation
}

Ramli bin Saadon, Ishak bin Saat, Khairi bin Ariffin, Baharuddin bin Jabar

To Link this Article: http://dx.doi.org/10.6007/IJARBSS/v9-i7/6188

DOI: $10.6007 /$ IJARBSS/v9-i7/6188

Received: 22 May 2019, Revised: 18 June 2019, Accepted: 29 June 2019

Published Online: 22 July 2019

In-Text Citation: (Saadon, Saat, Ariffin, \& Jabar, 2019)

To Cite this Article: Saadon, R. bin, Saat, I. bin, Ariffin, K. bin, \& Jabar, B. bin. (2019). Evaluation of the Economic Theme in Historical Curriculum in Middle School in Providing Entrepreneurial Spirit Generation. International Journal of Academic Research in Business and Social Sciences, 9(7), 901-908.

Copyright: (C) 2019 The Author(s)

Published by Human Resource Management Academic Research Society (www.hrmars.com)

This article is published under the Creative Commons Attribution (CC BY 4.0) license. Anyone may reproduce, distribute, translate and create derivative works of this article (for both commercial and non-commercial purposes), subject to full attribution to the original publication and authors. The full terms of this license may be seen

at: http://creativecommons.org/licences/by/4.0/legalcode

\section{Vol. 9, No. 7, 2019, Pg. 901 - 908}

Full Terms \& Conditions of access and use can be found at http://hrmars.com/index.php/pages/detail/publication-ethics 


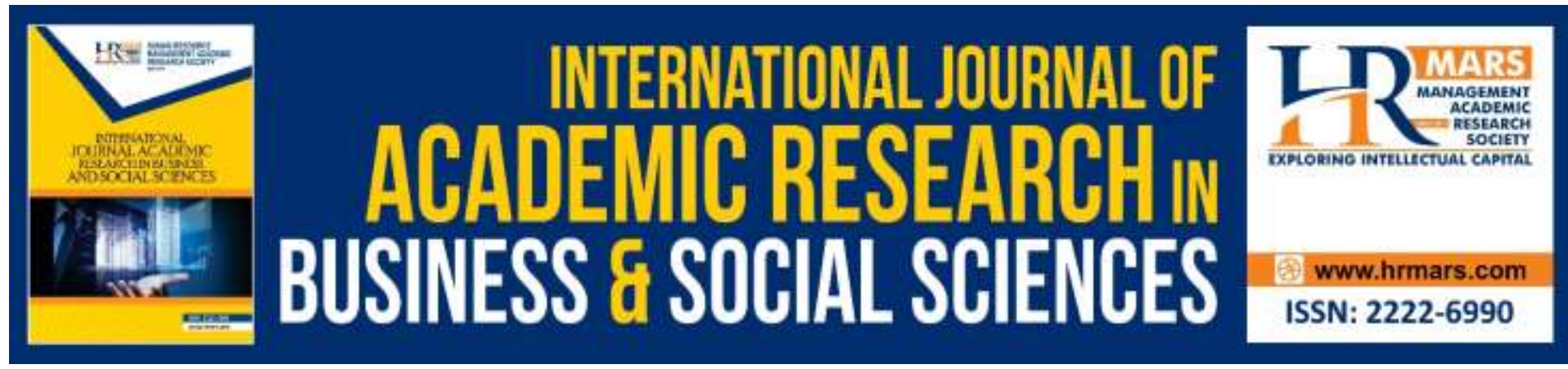

\title{
Evaluation of the Economic Theme in Historical Curriculum in Middle School in Providing Entrepreneurial Spirit Generation
}

\author{
Ramli bin Saadon, Ishak bin Saat, Khairi bin Ariffin, Baharuddin \\ bin Jabar \\ Sultan Idris Education University, Tanjung Malim, Perak \\ Email: ramli.saadon@fsk.upsi.edu.my, ishaksaat@fsk@upsi.edu.my, \\ khairiariffin@fsk.upsi.edu.my, baharuddin@fsk.upsi.edu.my
}

\begin{abstract}
This study aims to assess the mastery of students who study the historical subjects based on the economic title and study the ability of students to absorb the various entrepreneurial concepts. The concept of entrepreneurship can be achieved properly by students because the theme or the economic title is described in various aspects of its importance and also the weakness by the teacher who teaches the subject of history. Through the economic title that contained in the historical curriculum, various economic activities that have become historical materials are taught by historical teachers. The finding shows that there is a lack in the context of the ability of students to study the economic theme as most respondents only master the historical facts and use less of these facts to see the importance of learning the economic themes in historical learning. There are respondents who just state that with a business can generate wealth. However, respondents are less likely to say about raw materials that can be created on different forms of goods through creative ideas. The conclusions from this study found that students studying historical subjects have not reached the level of analysis and evaluated historical facts leading to the mastery of various concepts, especially entrepreneurship. The implication of the study requires that teachers, especially history subject to be taught at school level, not only emphasize historical facts. It is important so that among the student whose studying economic themes in historical subjects in constructing various meanings of career as entrepreneurs in the future.
\end{abstract}

\section{Introduction}

History subjects become core subjects in primary and secondary schools. History is a discipline that involves events in the past. The historical curriculum in the secondary school of economic themes is a popular theme learned by students. All students must master the facts and interpret the various economic activities whether they occur in Malaysia or overseas. The economic theme in the history subject includes trade, business and entrepreneurial activities that occur in a history context of the world and the regional. Hence the historical subjects 
should be able to build fundamental awareness to all students that the field of entrepreneurship is an important career in the future. Historical teaching in the 21st century has undergone various changes, especially in teaching methods that involve the cultivation of patriotic attitudes towards the nation, race and religion. Therefore, the ability of the historical subjects in building the entrepreneurial base should be evaluated as this subject is based on the actual events of the past and on the basis of truth. In addition, students need to present ideas to solve problem solving, especially in the field of economics through high order thinking skills. Compared to other theoretical-based subjects, historical subjects provide a whole range of new aspects to be generated to see future interests based on predictive, innovative prophecy. Through this valuation it can bring savings to the efforts of the parties to know the characteristics of a student who has a consciousness as an entrepreneur in the future. The economic theme in the history subject allows students to absorb all the historical thinking skills in helping them to have directions after completing their schooling. This is what is expected of the 21st century generation who need to make entrepreneurs as their career. Historical knowledge that learned at the school's level deserves to provide space and an opportunity for students to define their career based on the economic themes embodied in the historical curriculum in secondary and primary schools.

\section{Research Issue}

The historical curriculum that taught in the high school in Malaysia contains a range of historical events whether revolves on theme or title of political, economic and social title. Therefore, the subject of history often leads to boredom for the students as it only discusses the rigid facts. If judged on historical events related to economic themes, there are past events covering agricultural, commercial, business and enterprise activities. However, this does not have much impact on students to look at and evaluate the economic themes to help their thinking to see the future optimistically in their career. The field of entrepreneurship should be imbued with the students as the pattern of development that has changed completely. The basics of change can be scrutinized from historical events that allow students to build various entrepreneurial concepts to enable them to compete and solving problems in their future career. Historical themes that contain the economic themes taught by history teachers need a new approach so that students can absorb high-level thinking in the future and are also prepared with challenging careers facing the industrial revolution 4.0. Therefore, the economic theme should be able to provide students who are able to clearly see the economic advancement in the effort to provide a solid entrepreneurial base.

\section{Conclusion of Learning Economic Theme in Historical Subjects in Providing the Generation of Entrepreneurship}

Entrepreneurs not only involve businesses but more than that. Entrepreneurs need creativity in developing business to a higher level as well as the ability to make future expectations of the changes that took place. Therefore, in the Secondary School Standard Curriculum (2015) outlines the following in providing the young generation of entrepreneurship:

1. The application of entrepreneurial elements is to aimed characterizing and entrepreneurship practices into a culture among students.

2. Entrepreneurship features can be applied in teaching and learning through activities that can cultivate attitudes such as diligence, honesty, trust and responsibility as well as developing creative and innovative minds to drive ideas into the marketplace. 
Based on the above features it is clear that the construction of the entrepreneurship can be realized if the historical teaching based on the economic theme can be generated creatively so as touch the mind of the student to master the important aspects as an entrepreneur. Entrepreneurs are not just doing business matter but entrepreneurs are able to see the history of goods and services for the present and future. Norashidah et. al. (2009) there is a study conducted on entrepreneurial basics that emphasize on entrepreneurial thinking that helps the entrepreneurship mindset to be associated with the experience and knowledge in the classroom that should be used as a teaching material particularly the economic theme. Therefore, historical teachers are urgently required to move history lessons that discuss economic themes in order to raise the idea of entrepreneurship based on the question of accountability based on economic history which will surely tell the history of development as well as changes in economic activity. The answers of the students should be able to be reproduced by teachers based on the value of entrepreneurship that can be expected in the students' minds. Hence the question situation can help the students to come up with ideas about economic developments that requires entrepreneur action.

\section{THE THEME OF THE ECONOMIC HISTORY OF FORM2}

\section{ECONOMIC ACTIVITIES OF COMMON COMMUNITY}

The kingdom of Champa, Funan, Angkor, Majapahit and Srivijaya each run agricultural activities due to fertile places and land. Systematic irrigation systems from rivers also play an important role in their agricultural activities. Among the best selling are spices and other crops such as sugarcane, nuts, bananas and coconuts.

Each of these big kingdoms has its own port and its traded goods. This active trade attracted the attention of foreign traders to trade in the Malay World. Like the Arabian and Persian governments that carry items such as pottery, perfume, and beads. While Indian traders carry cotton and various precious stones.

This expanded trading activity has made the shipbuilding industry more advanced. The community of Malays also master the skills of shipbuilding and skilled in sailing science. Apart from farming, the Malay Kingdom Government is also well-known for forest products and marine products. Like agricultural activities, the people of the Malay Kingdom Government only seek forest produce and marine products only for daily necessities, but when the proceeds are more than necessary and excessive, they are then traded. Among the traded forest products are gaharu, bird's nest, cane and lime. While between sea produce is gamat, kelp and pearl.

The community of Malays involved in mining and manufacturing activities. Among those who received the welcome of foreign traders were gold, silver and iron ore. While they always make gold jewelery, pottery, coconut vinegar and salt.

\section{ECONOMIC ACTIVITIES OF SABAH AND SARAWAK COMMUNITY}

Daily activities in Sabah and Sarawak are influenced by their terrain. The shape of the face of the earth consists of the coast, the river estuary, and the deep. Peoples are live on the shores usually engage in trading, fishing, making boats, and sago bussiness. Peoples that live in the river valley, do the planting of rice, vegetables and fruits. People who are live in the interior area are engaged in collecting forest products, hunting wild animals and planting paddy. (DSKP Form 2, KPM) 
The passage above is an example of an economic theme that needs to be learned by form two students and in the event of historical teaching, then the value of entrepreneurship can be applied to the student's thinking when the theme is taught by the teacher. What's important is the ability of the teacher to achieve the entrepreneurial mindset based on the content of the economic history studied. Historical teachers does not teach the meaning of the entrepreneurial meaning, but providing a young generation with an idea of entrepreneurship is very important.

\section{Analysis of Data and Discussion}

The data collected are based on historical tests based on economic themes that deal with entrepreneurial aspects. In addition, the conversation techniques among the students sample covering schools in urban, semi-urban and rural areas were conducted. An important aspect of interviews among students is related to economic teaching with an economic theme. Data based on simple tests for students to develop economic themes to achieve meaning and entrepreneurial concepts in the minds of the students to see their future career.

\section{Study the level of Student Awareness in Entrepreneurship Culture through Economic themes in the Historical Curriculum.}

Through the historical subject of almost eighty percent (80\%) respondents among the three and four-tier students selected from some urban and rural schools only mastered historical facts and were unable to make a leap against the economic themes that were studied. Therefore, students are less able to see economic developments that can bring various implications in building a career that has existed in the historical context. In the context of the tin ore industry theme which leads to the development of the transportation system as well as the development of new cities, it is appropriate to build the basic concepts of entrepreneurs such as in making decision, creative and innovative. Nevertheless, only ten percent $(10 \%)$ of students try to see that economic themes can be linked to the opportunity to develop something new to generate the economy. Amongst the students are not able to see the impact of tin mining that can open up various business and entrepreneurial potentials. This aspect is not seen as an effort to solve various economic problems in the future. While the existence of a new city allows a variety of creative and innovative industries to be created. The transportation system should provide entrepreneurs who look at diversified scaling systems. Therefore, the results of the rubric provided are not good enough for students in the field of entrepreneurship for their future career.

\section{Discuss the Importance of the Economic theme in the Historical Curriculum to help the Younger Generation become Cultured Entrepreneurs}

On average, nearly ninety percent $(90 \%)$ of students can not elaborate on the importance of the economic theme in looking at the career opportunities as a result of economic development. Therefore, there is a barrier when students studying historical subjects related to economic themes because of the ability to use the economic theme to generate thinking skills do not occur. Hence, students' answers are very loose and general in looking at the economic themes that have been taught in historical subjects and the inability to link economic history to see future changes only bring losses to students to see the future in economic development. This situation needs to be seen in the context of the teacher teaches based on a solely historical facts. Nearly eighty-five percent (85\%) of respondents amongst 
students are not capable to propel high order thinking. Among the respondents who have learned the theme of agriculture, they simply state that they can grow vegetables and sell it to earn money. This illustrates that the concept of entrepreneurship is not achieved on the historical teacher factor which does not apply the value of the economic theme in the teaching and learning process. This is likely because historical teachers do not build a question of history teaching so that the economic themes reach a high level of thinking. Therefore, it is clear that the concept of entrepreneurship can not be applied even though historical teaching has the potential to mobilize entrepreneurship. If data is viewed among students who complete the Malaysian Certificate of Education (SPM) only about fourty percent (40\%) can continue their studies at the university level. Hence, nearly sixty percent (60\%) should be prepared with various opportunities as entrepreneurs based on existing economic developments such as agriculture industry and also services. Therefore, the economic theme in teaching should only be taught in a string of facts simply to disrupt the soul of the younger generation whose reality must be faced with a great fierce economic competition in the future. The importance of the economic theme is the application of value as stated in DSKP (2015) in the history curriculum in high school.

\section{Analyze the Ability of Students to Predict Future Based on Knowledge through Economic Themes in the Historical Curriculum}

In teaching and learning the history of various approaches is usually practiced by historical teachers to help students to master historical facts, so students can use historical facts to predict their future. The ability to predict the future of historical facts can help students to be optimistic about their future. Yet almost ninety-five percent (95\%) among students who became the respondents in this study did not have the ability to see their future. This is why in the current development of the country that the changing patterns of work have led young people to become exploits while the economic opportunities are wide open.Economic development would requires entrepreneurs in driving the country's economic development. Ones of the element that is likely to meet the features of an entrepreneur is the development of online business. Nearly eighty percent (80\%) respodents state that they engage in online business but is not able to state how to do that type of the bussiness. In the history of primary school there is a headline of communication development started with the creation of a telegraph system. Nearly one hundred percent $(100 \%)$ of respondents have not stated that they need to increase knowledge to become a successful entrepreneur, especially the use of information technology. In the historical curriculum, historical content (facts) are emphasized as well as the various teaching activities expressed as suggestions. However, the historical curriculum relies heavily on the ability of teachers to deliver such content and as stated in the Education Development Plan (2013-2025) that the role of teachers in the classroom is crucial in generating creative and innovative thinking. Therefore, high level thinking practice aspects should be given serious emphasis. It is hoped that the responsible party will need a history teaching approach so that the history teachers do not teach solely the historical facts as the most important thing. While there is a more important aspect of using these facts to help students think in a more optimistic way to provide a more optimistic future concept. The young generation who are optimistic about seeing the future can help the country's development. 


\section{Evaluate the Ability of Students in Entrepreneurship through the Mastery of Economic themes in the Historical Curriculum}

From test and conversation with respondents, all the themes of economic history can not be moved by respondents to a higher level. Hence, almost ninety-five percent (95\%) of respondents among students are unable to use historical facts with economic themes to see the future in their careers. They are still focused on the old thinking style in determining the pattern of work. While the reality of employment in the public and private sectors is no longer able to accommodate the increase in student graduates at Malaysian Certificate of Education (SPM), Malaysian Higher Education Certificate, Diploma and Bachelor Degree. This situation is very alarming. The rigid and deadly of studying history continues to face death and does not help the entrepreneurial mindset especially in empowering entrepreneurship. Whether the disadvantages of a pupil or a teacher are still necessary for a detailed study. But it is clear that all study instruments presented to the sample can not be developed by students who just write some historical facts and it is difficult to see them using ideas or entrepreneurial thinking. All historical facts can be said to have no meaning as something related to the student himself. Therefore, students place historical facts as something separate with everyday student life. This would have been very disadvantageous because the entrepreneurial mindset should be in the mindset since they were in school again.

\section{Conclusion}

The preparation of the younger generation in entrepreneurship is indispensable. The changing nature of a drastic country requires creative action on the younger generation to be prepared with innovative thinking in developing the country's economy. Therefore, economic themes in historical subjects should be a mechanism in building entrepreneurship when the historical teacher carries out the teaching and learning process in the classroom. Based on the economic theme in the history of questioning techniques, it is hoped that students studying history are conscious and sensitive to economic changes in the past and are able to make future expectations for their world of career.

Acknowledgement

This article was a result of University Research Grant (GPU) funded by Universiti Pendidikan Sultan Idris. Research under the supervision of Research, Management and Innovation Centre (RMIC) Universiti Pendidikan Sultan Idris. Research code: 2017-0286-107-01

\section{References}

Ghazali, A. Z. (2005) Pasir Salak, Pusat Gerakan Menentang British di Perak, Yayasan Perak, Melissa, A., Norazalina, M. G. \& Sazali. (2007), Pendekatan Proses Dalam Pengajaran dan Pembelajaran.

Angelo, Thomas, A. \& Cross, K. P. (1993), Classroom assessment techniques: A handbook for college teachers, San Francisco: Jossey- Bass Publisher.

Ausubel, David, P. (1967), Learning Theory and classroom Practice, Ontario.

Baron, Joan, B. and Sternbergs, R. J.(ed), (1987), Teaching Thinking Skills: Theory and practice, New York: Longman.

Block, J. H. (1971) Mastery Learning: Theory and Practice, New York: Holt, Rinehart \& Winston. 
Bloom, B. S., Englehart, M. D., Furst, E. J., Hill, W. H. \& Krathwohl, D. R.(1956), Taxonomy of educational objectives: The classification of educational objective, Book 1, Cognitive domain, New York: Logman.

Bloom, B. S. (1981) All Our Children learning, New York: McGraw-Hill

Carroll, B. S. (1963). A model of school learning. Teacher College Record.

Cavana, R. Y., Delahaye, B. L. \& Sekaran, U. (2001)"Applied Business Research, Qualitative Method". Milton Queensland. John Willey \& Sons Australia, Ltd.

Colton. (1978) A History of the Modern World, New York: Alferd A. Knopf, fifth edition.

Philips, L. (2008) teaching History, Developing as a Reflective Secondary Teacher, SAGE. London,

Lorin, W., Anderson and David R. K. (2001)A Taxonomy for learning teaching and Assessing, London.

Hashim, N., Othman, N. \& Buang, N. (2009), “Konsep Kesediaan Keusahawanan Berdasarkan Kajian Kes Usahawan Industri Kecil dan Sederhana(IKS) di Malaysia, "Jurnal Pendidikan 34(1): 187-203. 